\title{
Porokeratotic eccrine and hair follicle nevus: a report of two cases and review of the literature*
}

\author{
Alfredo Daniel Agulló-Pérez ${ }^{1,2}$ \\ Alicia Córdoba-Iturriagagoitia ${ }^{3}$
}

\author{
Miguel Ángel Resano-Abarzuza ${ }^{3}$ \\ Juan Ignacio Yanguas-Bayona ${ }^{2}$
}

DOI: http:/ /dx.doi.org/10.1590/abd1806-4841.20176536

\begin{abstract}
Porokeratotic eccrine and hair follicle nevus is a very rare non-hereditary disorder of keratinization with eccrine and hair follicle involvement with only 9 cases described in the literature. In 2009 the term porokeratotic anexial ostial nevus was proposed to comprehend porokeratotic eccrine and hair follicle nevus and a related and more common process without follicular involvement: porokeratotic eccrine ostial and dermal duct nevus Recent findings suggest that both entities may be produced by a mutation in GJB2 gene, which is associated to KID syndrome. Herein we report 2 cases of porokeratotic eccrine and hair follicle nevus and review the existing cases in the Spanish and English literature.
\end{abstract}

Keywords: Hamartoma; Keratinocytes; Nevus; Pediatrics

\section{INTRODUCTION}

Porokeratotic eccrine and hair follicle nevus (PEHFN) is a very rare nonhereditary disorder of keratinization with eccrine and hair follicle involvement, first described by Ralph J. Coskey et al. in 1982. ${ }^{1}$ Clinically it is characterized by asymptomatic linear hiperkeratotic papules or plaques often in a linear arrangement. Its histologic hallmark is a dilated eccrine acrosyringia and a dilated acrotrichia with an overlaying cornoid lamella. In 2009 the term porokeratotic anexial ostial nevus (PAON) was proposed to comprehend PEHFN and a related process without follicular involvement: porokeratotic eccrine ostial and dermal duct nevus (PEODDN). Herein we report 2 cases of PEHFN and review the existing cases in the Spanish and English literature.

\section{CASE REPORT}

A full-term white female newborn with no relevant family history had skin lesions located on her scalp, neck, trunk, right up- per and low limbs and right foot. Lesions had their onset at birth as linear whitish keratotic papules and plaques with erythematous component (Figure 1A and 1B). A systemic examination revealed no neurological or skeletal abnormalities. A skin biopsy was nondiagnostic but ruled out the possibility of incontinentia pigmenti.

Over the next 2 years, scalp, trunk and limb lesions gradually involuted and back, foot and sole lesions become less erythematous and more hyperkeratotic, some of them with comedo-like whitish colored keratin at their center (Figure 1C and 1D).

Skin biopsies taken from the lesions on the lateral face of the dorsum of the right foot showed acanthosis and papillomatosis with tiers of columns of parakeratosis over an epidermal invagination, with dyskeratotic keratinocytes and loss of the granular layer. These multiple parakeratotic foci occurred characteristically overlying both acrothrichia and acrosyringia (Figure 1E, 1F and 1G). Lesions did not respond to topical tazarotene.

\footnotetext{
Study submitted in 27.09.2016

Approved by the Advisory Board and accepted for publication on 25.11.2016

* Study conducted at the Dermatology and Pathology services, Complejo Hospitalario de Navarra, Pamplona, Navarra, Spain.

Financial Support: None.

Conflict of Interests: None.
} 
A 31-year-old man without any relevant medical history had skin lesions located on his left axillae. Lesions had been stable since their onset when he was 5 years old. Dermatologic examination revealed red to pink keratotic coalescent papules, some with whitish central spires over the left axillae (Figure 2A and 2B). Histologic examination demonstrated an irregular acanthosis, columns of parakeratosis with absent granular layer located at the acrothrichia and overlaying epidermal invaginations located over eccrine ducts. In reticular dermis dilated eccrine and apocrine glands were noticed
(Figure 2C, 2D and 2E). Topical methylprednisolone cream and pimecrolimus cream $0.1 \%$ were applied with minimal improvement. After 9 years of follow up, lesions remained stable.

\section{DISCUSSION}

PEHFN is a very rare nonhereditary adnexal hamartoma of eccrine and hair follicle components. A literature review revealed only 9 reported cases (Table). ${ }^{1-7}$

Some authors have proposed that PEHFN and PEODDN are
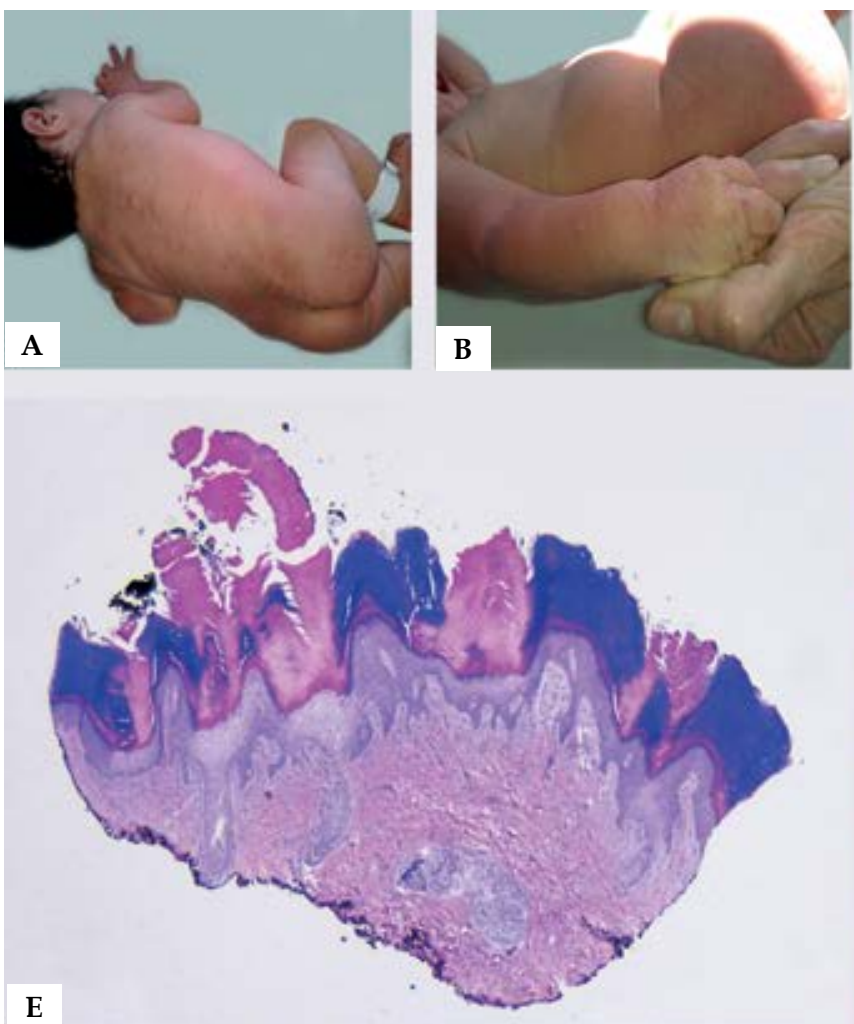
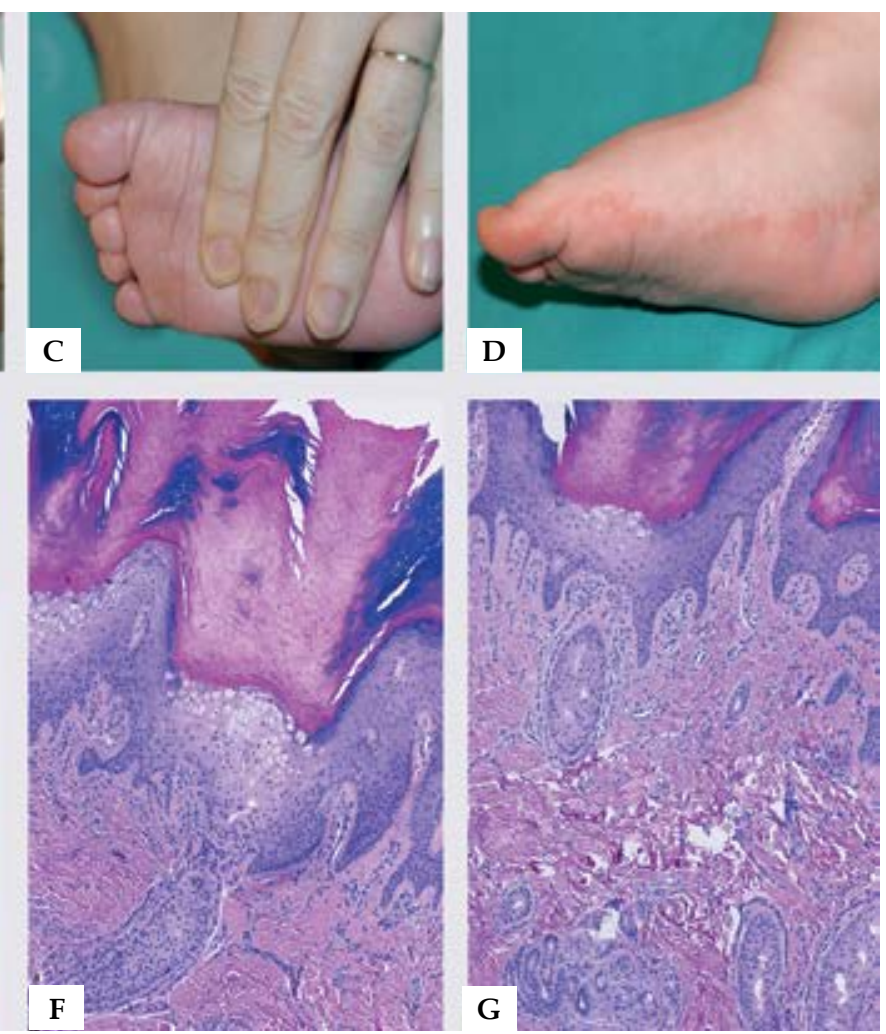

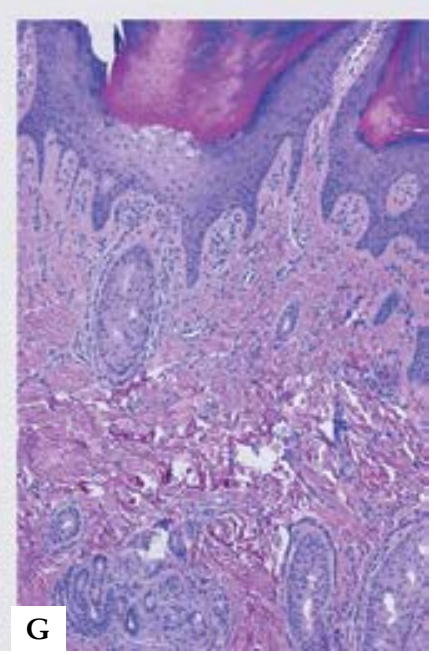

Figure 1: A \& B: Erythematous keratotic plaques in Blaschko linear distribution over the back and left arm in the newborn. C \& D: Linear whitish keratotic filiform papules on the sole and on the medial aspect of the right foot with an erythematous component in latter (age 2 years old). E: Alternating columns of orto and parakeratosis. Each band is located over acrothrichia and acrosyringia, a follicle and an eccrine gland underlies a cornoid lamella (Hematoxylin \& eosin,X2). F \& G: Detail of the eccrine duct and the eccrine gland (Hematoxylin \& eosin, X10)

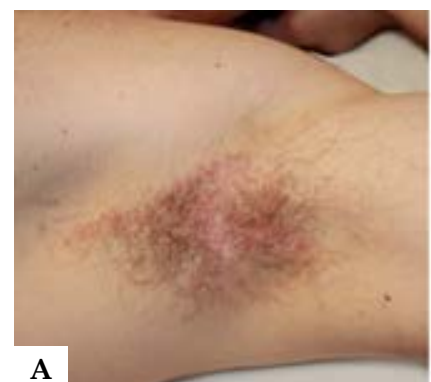

A
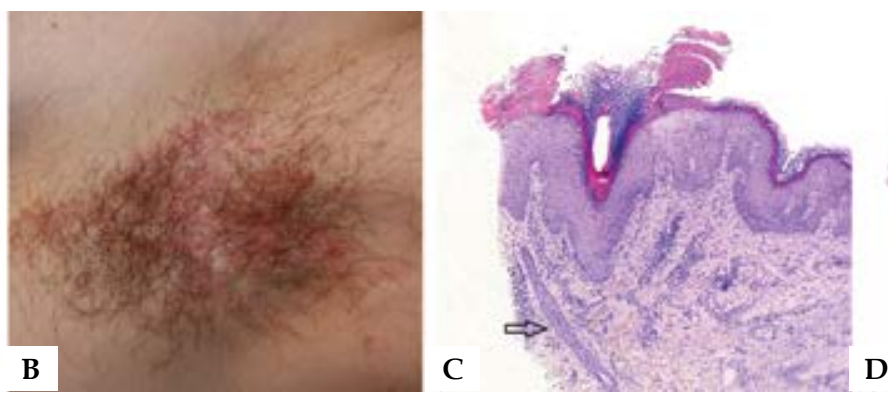

Figure 2: A: Red to Pink keratotic coalescent papules, some with whitish central spires over the left axillae. B: Detail. C: cornoid lamella over an acrosyringia with an underlying eccrine duct (arrow) and other cornoid lamella overlaying an acrothrichium (Hematoxylin \& eosin, X2). D: Parakeratosis band overlaying an acrothrichium (Hematoxylin \& eosin, X10) 
TABLE 1: Compilation of PEHFN cases

\begin{tabular}{|c|c|c|c|c|c|c|c|}
\hline Case & Author/ year & $\begin{array}{l}\text { Age of onset/ } \\
\text { Gender }\end{array}$ & U or B & Distribution & Morphology & Clinical course & $\begin{array}{l}\text { Treatment/Response } \\
\text { to therapy }\end{array}$ \\
\hline 1 (1) & Coskey/ 1982 & $2 \mathrm{Y} / \mathrm{F}$ & U & $\begin{array}{l}\text { Forearm, wrist, } \\
\text { palms }\end{array}$ & $\begin{array}{l}\text { Linear erythematous, slightly } \\
\text { scaly plaque and filiform } \\
\text { papules with whitish-colored } \\
\text { keratin at their center. }\end{array}$ & $\begin{array}{l}\text { Increased in size } \\
\text { proportionately as } \\
\text { patient grew }\end{array}$ & - \\
\hline $2(6)$ & $\begin{array}{l}\text { Kroumpouzos/ } \\
1999\end{array}$ & Birth/F & B & $\begin{array}{l}\text { Scalp, neck, } \\
\text { trunk, } \\
\text { extremities } \\
\text { (Generalized) }\end{array}$ & $\begin{array}{l}\text { Yellow to brown keratotic } \\
\text { plaques over patches of hair } \\
\text { loss. Hyperkeratotic plaques. } \\
\text { Red to brown, scaly, verrucous } \\
\text { plaques in a symmetrical-linear } \\
\text { and in random patterns }\end{array}$ & $\begin{array}{l}\text { Increased in size } \\
\text { proportionately as } \\
\text { patient grew }\end{array}$ & - \\
\hline $3(3)$ & Goddard/ 2009 & Birth/F & B & $\begin{array}{l}\text { Face, neck, } \\
\text { trunk, arms, but- } \\
\text { tocks, groin, legs, } \\
\text { back of hands } \\
\text { and feet, palms }\end{array}$ & $\begin{array}{l}\text { Erythematous and atrophic } \\
\text { erosions and fissures in Blasch- } \\
\text { ko linear distribution }\end{array}$ & $\begin{array}{l}\text { Spreading, becoming } \\
\text { more hyperkeratotic } \\
\text { with fragile atrophic } \\
\text { plaques and less ery- } \\
\text { thematous component }\end{array}$ & $\begin{array}{l}\text { Pulsed dyed laser, } \\
\text { tazarotene } 0.1 \% \text { cream, } \\
\text { 5-fluorouracil } 5 \% \\
\text { cream/ No effect }\end{array}$ \\
\hline $4(3)$ & Goddard/ 2009 & Birth/F & B & $\begin{array}{l}\text { Trunk. Arms } \\
\text { and legs. Fourth } \\
\text { finger, nail and } \\
\text { plantar aspect of } \\
\mathrm{r} \text { foot }\end{array}$ & $\begin{array}{l}\text { Hiperkertatotic linear plaques } \\
\text { with central hypopigmented } \\
\text { atrophic plaques. Erythematous } \\
\text { papules and tense bullae within } \\
\text { areas of hyperpigmentation }\end{array}$ & $\begin{array}{l}\text { Stable till age of } 32 \text {, } \\
\text { when developed ery- } \\
\text { thema, pruritic blisters } \\
\text { within plaques later } \\
\text { ulcers, and finally SCC } \\
\text { in lesional skin }\end{array}$ & $\begin{array}{l}\text { Minocycline } 100 \mathrm{mg} \text {, } \\
\text { Tretionin } 0,1 \% \text {, Tazaro- } \\
\text { ten 0,05\%, cryotherapy, } \\
\text { fluocinonide/ Minimal } \\
\text { improvement }\end{array}$ \\
\hline $5(3)$ & Goddard/ 2009 & Birth/F & B & $\begin{array}{l}\text { Inguinal area, } \\
\mathrm{r} \text { arm, } 1 \text { inner } \\
\text { thigh, } 1 \text { hand }\end{array}$ & $\begin{array}{l}\text { Rugged pink to gray-brown } \\
\text { linear lichenified plaques with } \\
\text { peripheral rim of scale, in Blas- } \\
\text { chko linear distribution and } \\
\text { annular macules with atrophic } \\
\text { centers }\end{array}$ & $\begin{array}{l}\text { Thickened over time, } \\
\text { transitioning from ery- } \\
\text { thema to gray-brown } \\
\text { color }\end{array}$ & $\begin{array}{l}\text { Mometasone cream/ } \\
\text { slightly improvement, } \\
\text { irritation }\end{array}$ \\
\hline $6(7)$ & $\begin{array}{l}\text { Martorell-Cala- } \\
\text { tayud/ } 2010\end{array}$ & Birth/M & $\mathrm{U}$ & $\begin{array}{l}\mathrm{R} \text { forearm, } \mathrm{r} \\
\text { wrist, upper } \mathrm{r} \\
\text { trunk }\end{array}$ & $\begin{array}{l}\text { Hyperkeratotic, whorled, linear } \\
\text { plaques with hypopigmented } \\
\text { atrophic center }\end{array}$ & $\begin{array}{l}\text { Increased in size } \\
\text { proportionately as } \\
\text { patient grew }\end{array}$ & - \\
\hline $7(2)$ & Criscione/ 2010 & $15 \mathrm{Y} / \mathrm{F}$ & B & $\begin{array}{l}\text { Legs, trunk, } \\
\text { cheeks }\end{array}$ & $\begin{array}{l}\text { Scattered brown keratotic pa- } \\
\text { pules, multiple tiny yellow and } \\
\text { skin-colored filiform papules, } \\
\text { randomly distributed }\end{array}$ & $\begin{array}{l}\text { Gradual spreading } \\
\text { of facial papules, } \\
\text { trunk and leg papules } \\
\text { coalesced into thin } \\
\text { plaques }\end{array}$ & $\begin{array}{l}\text { Cryotherapy, } \mathrm{t} \\
\text { retinoids, steroids, } \\
\text { salicyclic acid \& } \\
\text { urea/ ineffective. } \\
\text { Carbon dioxide laser/ } \\
\text { moderate improvement }\end{array}$ \\
\hline $8(5)$ & $\begin{array}{l}\text { Mayorga-Velás- } \\
\text { quez/ } 2013\end{array}$ & $21 / \mathrm{M}$ & B & Cheeks & Brown verrucous plaques & $\begin{array}{l}\text { Gradual growing over } \\
6 \text { months }\end{array}$ & - \\
\hline $9(4)$ & $\begin{array}{l}\text { Llamas-Velasco } \\
\text { / } 2015\end{array}$ & $2 \mathrm{Y} / \mathrm{M}$ & B & $\begin{array}{l}\text { Axillae, groins, } \\
\text { thighs }\end{array}$ & $\begin{array}{l}\text { Plaques composed of multiple } \\
\text { slightly erythematous keratotic } \\
\text { papules, some with whitish } \\
\text { central spires vertically projec- } \\
\text { ted from their pits }\end{array}$ & - & $\begin{array}{l}\text { Carbon dioxide laser/ } \\
\text { moderate improve- } \\
\text { ment, discrete recurren- } \\
\text { ce after treatment }\end{array}$ \\
\hline 10 & $\begin{array}{l}\text { Agulló-Pérez/ } \\
2016\end{array}$ & Birth/F & U & $\begin{array}{l}\text { Scalp, neck, } \\
\text { trunk, right } \\
\text { upper and lower } \\
\text { limbs. R sole }\end{array}$ & $\begin{array}{l}\text { Erythematous keratotic papu- } \\
\text { les and plaques in Blaschko } \\
\text { linear distribution. Filiform } \\
\text { brown papules with whitish } \\
\text { colored keratin at their center }\end{array}$ & $\begin{array}{l}\text { Some lesions experi- } \\
\text { mented gradual invo- } \\
\text { lution, other become } \\
\text { more hyperkeratotic } \\
\text { with less erythema- } \\
\text { tous component }\end{array}$ & $\begin{array}{l}\mathrm{T} \text { tazarotene/No } \\
\text { response }\end{array}$ \\
\hline 11 & $\begin{array}{l}\text { Agulló-Pérez/ } \\
2016\end{array}$ & $5 \mathrm{Y} / \mathrm{M}$ & U & Axillae & $\begin{array}{l}\text { Red to Pink keratotic coa- } \\
\text { lescent papules, some with } \\
\text { whitish central spires }\end{array}$ & Stable & $\begin{array}{l}\text { Pimecrolimus 0,1\%, } \\
\text { methylprednisolone/ } \\
\text { No effect }\end{array}$ \\
\hline
\end{tabular}

Y, years; F, female; M, male; U, unilateral; B, bilateral; SCC, squamous cell carcinoma; t, topical; r, right; l, left 
variants of the same process, differentiated by the adnexal structure or structures affected (eccrine and follicle or only eccrine structures) and by the level of involvement. According to studies on multiple sections, both are probably variants of the same process. ${ }^{3}$

PEHFN is slightly more common in women than in men. PEHFN is typically congenital or appears at young age but there are 2 cases of late-onset. ${ }^{2,5}$

The nevus typically appears as multiple asymptomatic, pink, red, yellow, whitish or brown hyperkeratotic verrucous papules and plaques, involving bilaterally extremities in a Blaschko-linear distribution, although trunk, face, neck and scalp can be affected. A comedo-like form (filiform papules with whitish-colored keratin center) has also been noticed. ${ }^{1,4}$ In congenital lesions, the erythematous component tends to disappear as the patient grows. There are 2 reported cases of systematized PEHFN and 2 cases with localized lesions (cheek and axillae). ${ }^{3,5,6}$ Approximately just a third of reported cases are unilateral. PEODDN lesions by contrast tend to be unilateral. ${ }^{4}$

PEHFN is most likely a mosaic condition due to postzygotic somatic mutations during embryogenesis. No consistent cutaneous or systemic associations exist, although concurrence with KID syndrome has been reported. ${ }^{2}$ Recently PEODDN has been considered as a mosaic form of KID as it may present mutations in a gap junction protein, connexin 26 (Cx26), encoded by the gene GJB2. ${ }^{8}$ This mutation alone has demonstrated to be sufficient to cause PEODDN.

${ }^{9}$ The fact that the 2 reported cases in adult patients appeared with a nonlinear distribution suggests that these cases could be related to acquired non-embryonic sporadic mutations. Further reports are needed to clarify this hypothesis.
Differential diagnosis of PEHFN includes linear porokeratosis, punctate porokeratosis, PEODDN, nevus comedonicus, epidermal nevus, inflammatory linear epidermal nevus, Goltz syndrome, incontinentia pigmenti and porokeratoma in isolated lesions.

PEHFN tends to persist and is not considered a premalignant lesion. There is one case of malignant transformation with development of multifocal squamous cell carcinoma. ${ }^{3}$ Due to the association of porokeratotic nevus with GJB2 mutation (mutation responsible for KID syndrome) and PEHFN with KID syndrome, individuals with PEHFN may be at risk of conceiving children with KID syndrome and should be counseled regarding this risk. Patients with generalized lesions are probably at greater risk. ${ }^{9}$

There is no effective treatment for PEHFN. Different treatment modalities have been reported such us pulsed dyed laser, CO2 laser, tazarotene, 5-fluoroacil, minocycline, tretionin, cryotherapy, topical steroids, salicylic acid and urea.

PEHFN responded to $\mathrm{CO}_{2}$ laser or cryotherapy (extremely painful) and slightly to mometasone, flucinonide, tretinoin or tazarotene. ${ }^{3,45}$ Surgical excision is an option for cases with limited body involvement.

In conclusion, PEHFN is a very uncommon dermatosis with a characteristic histology but a variable clinical expression. Very few cases have been reported in the literature to date. Existent data suggest that GJB2 mutation presented in PEODDN lesions may be responsible also for PEHFN. Further studies are required to confirm this mutation also in PEHFN, rule out other possible genetic alterations and reinforce the hypothesis of PEODDN and PEHFN as two faces of the same process (PAON).] 


\section{REFERENCES}

1. Dlo1. Coskey RJ, Mehregan AH, Hashimoto K. Porokeratotic eccrine duct and hair follicle nevus. J Am Acad Dermatol. 1982;6:940-3.

2. Criscione V, Lachiewicz A, Robinson-Bostom L, Grenier N, Dill SW. Porokeratotic eccrine duct and hair follicle nevus (PEHFN) associated with keratitis-ichthyosisdeafness (KID) syndrome. Pediatr Dermatol. 2010;27:514-7.

3. Goddard DS, Rogers M, Frieden IJ, Krol AL, White CR Jr, Jayaraman AG, et al. Widespread porokeratotic adnexal ostial nevus: clinical features and proposal of a new name unifying porokeratotic eccrine ostial and dermal duct nevus and porokeratotic eccrine and hair follicle nevus. J Am Acad Dermatol. 2009;61:1060.e1-14

4. Llamas-Velasco M, Hilty N, Kempf W. Porokeratotic adnexal ostial naevus: review on the entity and therapeutic approach. J Eur Acad Dermatol Venereol. 2015;29:2032-7.

5. Mayorga-Velásquez E, Sehtman A, Donatti L, Casas JG, Marini MA, Allevato MA. Nevo poroqueratósico ecrino y del ostium folicular en el rostro de un adulto. Arch Argent Dermatol. 2013:63:226-9.

6. Kroumpouzos G1, Stefanato CM, Wilkel CS, Bogaars H, Bhawan J. Systematized porokeratotic eccrine and hair follicle naevus: report of a case and review of the literature. Br J Dermatol. 1999;141:1092-6.

7. Martorell-Calatayud A, Colmenero I, Hernández-Martín A, Requena L, Torrelo A. Porokeratotic eccrine and hair follicle nevus. Am J Dermatopathol. 2010;32:529-30.

8. Easton JA, Donnelly S, Kamps MA, Steijlen PM, Martin PE, Tadini G, et al. Porokeratotic eccrine nevus may be caused by somatic connexin26 mutations. J Invest Dermatol. 2012;132:2184-91.

9. Levinsohn JL, McNiff JM, Antaya RJ, Choate KA. A Somatic p.G45E GJB2 Mutation Causing Porokeratotic Eccrine Ostial and Dermal Duct Nevus. JAMA Dermatol. 2015;151:638-41.
MAILING ADDRESS:

Alfredo Daniel Agulló Pérez

Centro Especialidades Principe de Viana,

Irunlarrea $\mathrm{N}^{\circ} 3$

Planta Baja

31008 - Pamplona, Spain.

Email: tegatreides@gmail.com

How to cite this article: Agulló-Pérez AD, Resano-Abarzuza MA, Córdoba-Iturriagagoitia A, Yanguas-Bayona JI. Porokeratotic eccrine and hair follicle nevus: a report of two cases and review of the literature. An Bras Dermatol. 2017;92(5 Suppl 1):121-5. 